\title{
Benzothiadiazole oligoene fatty acids: fluorescent dyes with large Stokes shifts
}

\author{
Lukas J. Patalag and Daniel B. Werz
}

\author{
Full Research Paper \\ Address: \\ Institut für Organische Chemie, Technische Universität Braunschweig, \\ Hagenring 30, 38106 Braunschweig, Germany \\ Email: \\ Daniel B.Werz - d.werz@tu-braunschweig.de \\ * Corresponding author \\ Keywords: \\ fatty acid; fluorescence; lipid; membrane; Stokes shift
}

Beilstein J. Org. Chem. 2016, 12, 2739-2747.

doi:10.3762/bjoc. 12.270

Received: 27 October 2016

Accepted: 01 December 2016

Published: 14 December 2016

This article is part of the Thematic Series "Lipids: fatty acids and derivatives, polyketides and isoprenoids".

Guest Editor: J. S. Dickschat

(C) 2016 Patalag and Werz; licensee Beilstein-Institut.

License and terms: see end of document.

\begin{abstract}
Herein, we report on the synthesis and characterization of novel fluorescent fatty acids with large Stokes shifts. Three examples consisting of the same number of carbon atoms and thus of similar chain length are presented differing in their degree of unsaturation. As major fluorogenic contributor at the terminus benzo $[c][1,2,5]$ thiadiazole was used. Respective syntheses based on Wittig reactions followed by iodine-mediated isomerization are presented. The absorption properties are modulated by the number of conjugated $\mathrm{C}=\mathrm{C}$ double bonds of the oligoene chain ranging from one to three. Large Stokes shifts of about $4900-5700 \mathrm{~cm}^{-1}$ and fluorescence quantum yields of up to 0.44 were observed.
\end{abstract}

\section{Introduction}

The membrane of living cells consists of a variety of lipids. More than 40 years ago, biological membranes were first described as Fluid Mosaic in which proteins were embedded [1]. During recent decades it became more and more clear that such a simple model is not sufficient to understand membrane dynamics and function. Often membrane domains are formed in which certain lipids, glycolipids or proteins are enriched [2-4]. Such domains - also called lipid rafts - do not only differ in their chemical composition, but also show different physical properties (e.g., differences in membrane thickness and stiffness, different diffusion coefficients etc.) $[5,6]$. Tools to investi-

gate lipid membranes are multifaceted; however, all optical methods are hampered by the missing absorption and fluorescence properties of natural occurring lipid components. Therefore, indirect methods are commonly employed. Either unnatural fluorescent dyes are inserted into the membrane (e.g., pyrene) or the hydrophilic part of lipids is utilized for the covalent attachment of fluorophores. Another possibility is the use of fluorescently labelled antibodies which bind membrane components such as the carbohydrate part of glycolipids $[7,8]$. A further alternative is to render the lipid and especially the fatty acid part fluorescently active by the introduction of 
fluorescent moieties (Figure 1). Prominent examples in this area are NBD- (nitrobenzoxadiazole) [9,10], BODIPY - (borondipyrromethene) [11,12], BOIMPY- (bis(borondifluoride)-8imidazodipyrromethene) [13] and pyrene-labeled fatty acids [14]. Of course, all these alterations might also affect the membrane structure and its dynamics. While the NBD-fluorophore suffers from unsuitable polarity, a pyrene motif disrupts the unpolar membrane core with high bulkiness. BODIPY and BOIMPY scaffolds on the other hand expose fluoride residues which might be able to interact with polarized $\mathrm{H}-\mathrm{X}$ bonds Therefore, we synthesized pentaene and hexaene fatty acids which bear five or six double bonds at the terminus or in the middle of the acyl chain [15]. Their slim shape mimics the natural geometry of a saturated hydrocarbon chain and should therefore only lead to minimal disturbances [16]. Nevertheless, we found that their stability with respect to both, oxygen and strong laser beams, is relatively low. The design of novel fluorescent fatty acids is therefore a challenging tightrope walk between advantageous spectroscopic properties, overall stability and a non-interfering molecular shape. As a promising contribu- tion we designed alternative fatty acids which are constructed as a combination of double bonds and benzo[c] $[1,2,5]$ thiadiazole as a relatively unpolar terminal headgroup (Figure 1). Its electron-withdrawing strength adds on the one hand significant stability towards acidic environments and should furthermore trigger a red-shift in absorption. As another strategic goal the fluorescent fatty acids were supposed to be equipped with very similar geometrical parameters differing only in their absorption and emission wavelengths. The grade of unsaturation as the sole geometrical difference thus provides a set of probes to study the effect of rigidified ethene moieties as straight-chain alkane surrogates within biological membranes.

\section{Results and Discussion Synthesis}

The most prominent methods to access oligoene structures are either cross-coupling reactions [17-19] or Wittig-type reactions [20-22]. The advantage of the latter ones is that they are often conducted at low temperatures and therefore are employed for sensitive compounds. However, a drawback of Wittig reactions<smiles>O=C(O)CCCCNc1ccc([N+](=O)[O-])c2nonc12</smiles>

NBD-labeled fatty acid<smiles></smiles>

BODIPY-labeled fatty acid<smiles>CC(C)(Cc1ccc2ccc3cccc4ccc1c2c34)C(=O)O</smiles>

pyrene-labeled fatty acid

previous work

pyrene-labeled fatty acid

BOIMPY-labeled fatty acid $\gamma_{14} \mathrm{COOH}$<smiles>Cc1ccc2n1B(F)c1c3n(c4ccccc14)B(F)N1C(/C=C/c4ccc(OCC(C)(C)C(=O)O)cc4)=CC=C3N21</smiles>

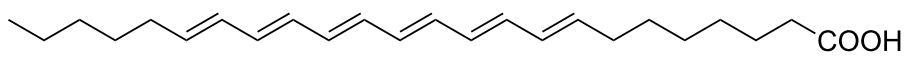

oligoene fatty acid<smiles>O=C(O)CCCCCC=Cc1cccc2nsnc12</smiles>

$(n=1,2,3)$

BTD-labeled fatty acids 
is the fact that the stereochemistry of the emerging double bond strongly depends on the type of substituent used. Aliphatic residues tend to give the $(Z)$-isomer. If the thermodynamically more stable $(E)$-isomer is needed, a subsequent isomerization has to take place.

To access the benzothiadiazole (BTD) fatty acid $\mathbf{3}$ with just one conjugated double bond we made use of the Wittig reaction starting with commercially available aldehyde 1 . As expected, the $(Z)$-isomer was the major product; thus, we performed a subsequent cis-trans isomerization with traces of iodine as catalyst (Scheme 1). It proved to be crucial to employ degassed hexane and to ensure a strict exclusion of oxygen. Considering both, the isomerization was finished just by removing the solvent while the yield of compound $\mathbf{3}$ was not hampered.

For a BTD fatty acid analogue of the same length, but of more extended conjugation we made use of the Horner-Wadsworth-Emmons (HWE) reaction. Phosphonate $\mathbf{4}$ was reacted with the respective aldehyde $\mathbf{1}$. In a facile three-step one-pot process the emerging $\alpha, \beta$-unsaturated ester $\mathbf{5}$ was immediately converted to the alcohol 6 in $87 \%$ yield in the presence of a Lewis acid and DIBAL at low temperatures. $\mathrm{MnO}_{2}$-mediated oxidation afforded the respective aldehyde that was immediately transformed by Wittig reaction. Iodine-catalyzed cis-trans isomerization yielded the desired fatty acid 7 in $35 \%$ over three steps (Scheme 2).

The analogue with three conjugated double bonds was accessed by a similar route that differs only in the type of the phosphonate being employed as starting material. Since three double bonds are required a tailor-made $\alpha, \beta$-unsaturated phosphonate $\mathbf{8}$ was used, which we already employed successfully in former oligoene syntheses [15]. Whereas the second double bond is the result of the HWE reaction the third one is generated in the final Wittig reaction furnishing BTD-equipped triene fatty acid 11c in an overall yield of $32 \%$ (Scheme 3 ). Notably, the ester intermediate 9 showed already a strong fluorescence at ambient

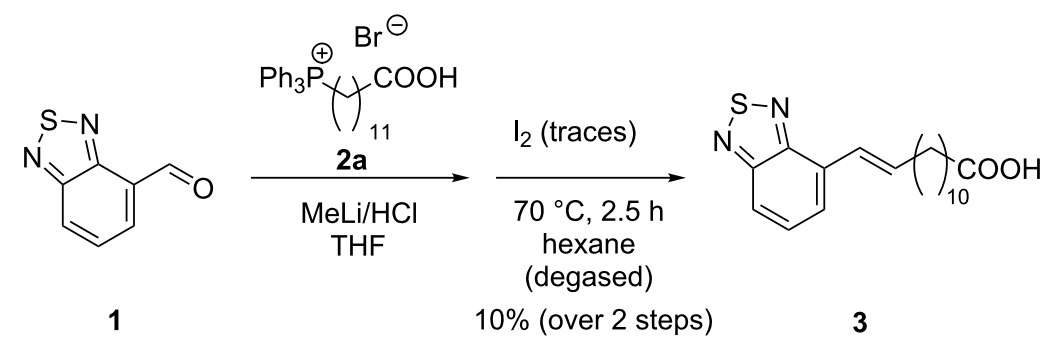

Scheme 1: Synthesis of fatty acid 3 with one olefinic unit.

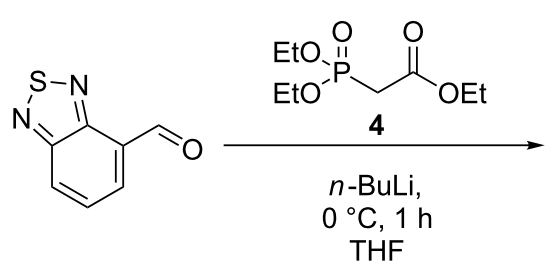

1<smiles>CCOC(=O)/C=C/c1cccc2nsnc12</smiles>

a) $\mathrm{BF}_{3} \cdot \mathrm{OEt}_{2}$ (1.3 equiv)

b) DIBAL (4 equiv)

$-78^{\circ} \mathrm{C}, 1 \mathrm{~h}$

$\mathrm{THF}$

$87 \%$

5

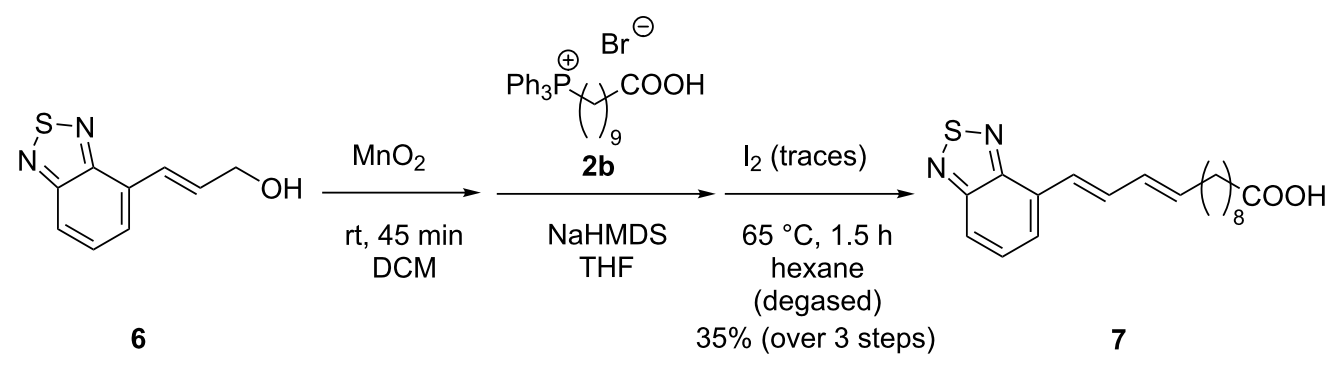

Scheme 2: Synthesis of fatty acid 7 with two olefinic units. 

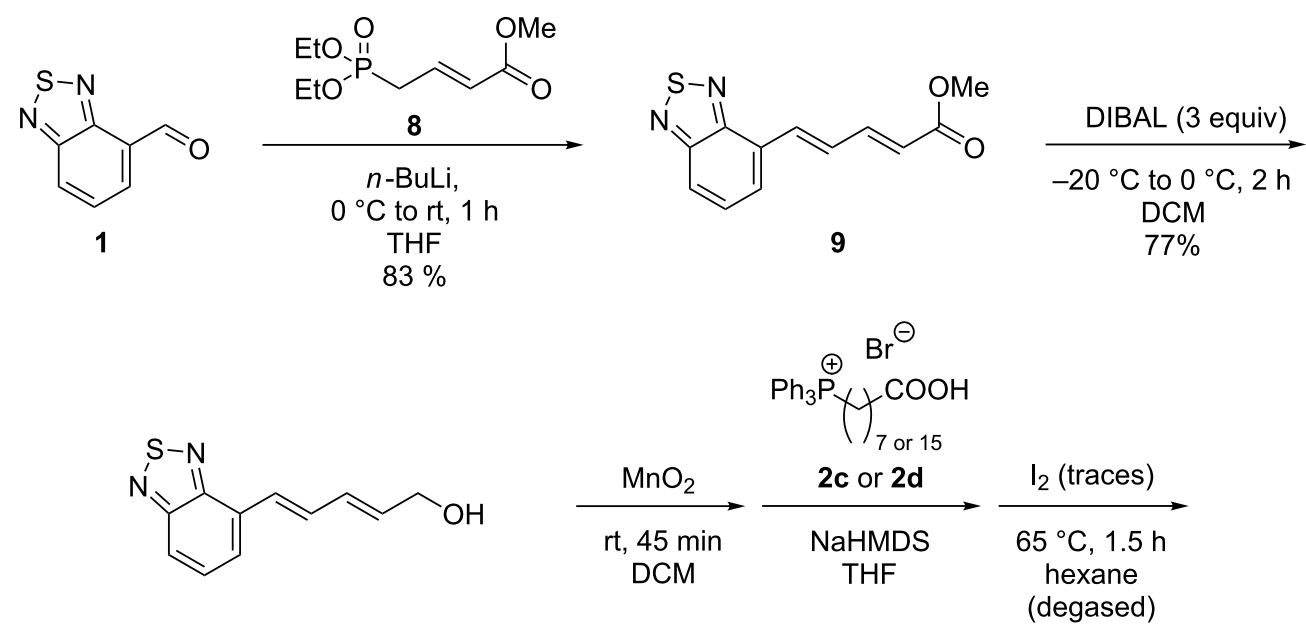

10

$32 \%$ (over 3 steps for $11 \mathrm{c}$ )<smiles>CC(C)(C)C=CC=CC=Cc1cccc2nsnc12</smiles>

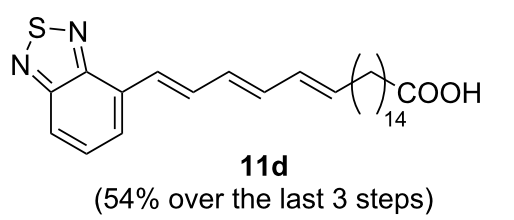

Scheme 3: Synthesis of fatty acid 11c with three olefinic units

light. By choosing a Wittig salt with a longer alkyl chain the synthesis of the fatty acid 11d with a chain of 21 carbon atoms in addition to the BTD unit was equally feasible.

\section{Spectroscopic properties and quantum chemical calculations}

If one follows the oligoene chain and includes the two s-cisshaped double bonds of the BTD headgroup one could regard the fluorogenic core as an oligoene with a geminal diimine acceptor group. Since oligoene absorptions are well-known we anticipated here to access a somehow red-shifted level of excitation energy. Indeed, a bathochromic shift of more than $60 \mathrm{~nm}$ relative to a corresponding underivatized oligoene moiety was observed in each case. As anticipated, $\lambda_{\max }$ values increase with a growing number of double bonds from $\mathbf{3}$ via $\mathbf{7}$ to $\mathbf{1 1}$ (Figure 2).

Concomitantly, the rather low attenuation coefficient at the longest wavelength absorption rises from $3.400 \mathrm{M}^{-1} \mathrm{~cm}^{-1}$ (7) to $11.000 \mathrm{M}^{-1} \mathrm{~cm}^{-1}$ for fatty acid $\mathbf{1 1}$ with three conjugated double bonds (Table 1). Fluorescence excitation spectra (not shown) for all three fluorophores pretty much coincide with the corresponding absorption spectra in Figure 2, which allows the fluorescence to be switched on at the longest wavelengths respectively.

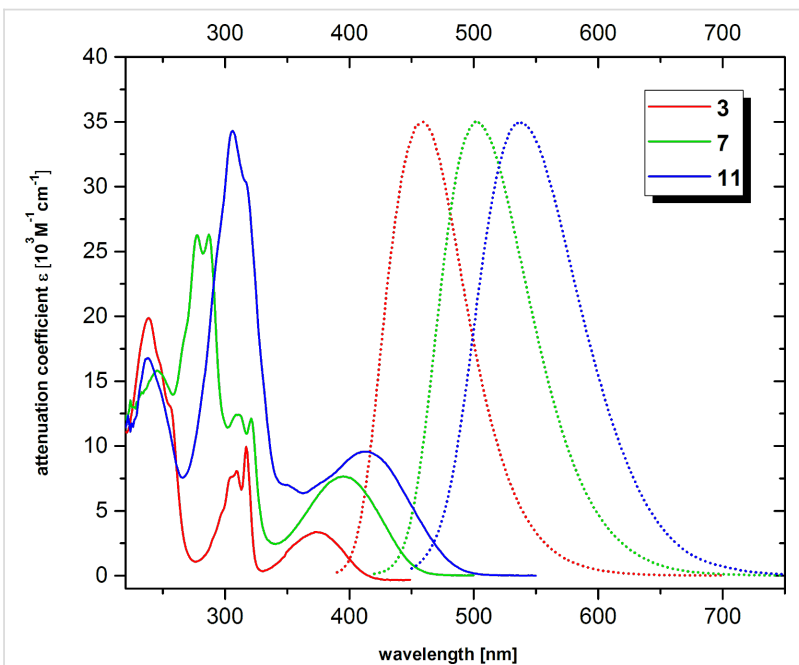

Figure 2: Absorption spectra of fatty acids 3, 7 and 11. Solid lines show the UV absorption while dashed lines show fluorescence emission. Excitation was performed at the longest wavelength in each case.

Stokes shifts are large $\left(\approx 5000 \mathrm{~cm}^{-1}\right)$ and increase in the same manner with the size of the $\pi$-system albeit to a smaller extent. These findings can be quite consistently rationalized when the frontier orbitals of the chromophoric cores (cc3, cc7, cc11) are taken into account. DFT calculations (B3LYP/6-311G(d,p)) reveal that the HOMO is predominantly located at the oligoene 
Table 1: Spectroscopic data of synthesized fatty acids in THF at room temperature. Attenuation coefficients $\varepsilon$ refer to the longest wavelength absorption peaks respectively.

\begin{tabular}{ccccccc} 
& $\lambda^{A}{ }_{\max }[\mathrm{nm}]$ & $\lambda_{\max }^{F_{m}[\mathrm{~nm}]}$ & $\varepsilon\left[10^{3} \mathrm{M}^{-1} \mathrm{~cm}^{-1}\right]$ & $\Delta \tilde{v}\left[\mathrm{~cm}^{-1}\right]$ & $\varphi_{F}(\mathrm{rt})$ & Brightness $\left[10^{3} \mathrm{M}^{-1} \mathrm{~cm}^{-1}\right]$ \\
\hline $\mathbf{3}$ & 374 & 459 & 3.4 & 4950 & 0.44 & 1.5 \\
$\mathbf{7}$ & 395 & 501 & 7.6 & 5360 & 0.33 & 2.5 \\
11c & 412 & 537 & 9.6 & 5650 & 0.18 & 1.7 \\
11d & 412 & 537 & 11.0 & 5650 & 0.18 & 2.0
\end{tabular}

chain while the LUMO is rather spread over the BTD terminus (Figure 3).

Indeed, further TD-DFT calculations (not shown) assign the longest wavelength absorptions of all three compounds to a high contribution of a HOMO-LUMO transition. Thus, the low overlap between both wavefunctions results in a small transition dipole moment and subsequently a quite weak absorption. The situation is even aggravated by the specific small angle $\left(\approx 64^{\circ}\right)$ between the oligoene and the longitudinal axis of the BTD moiety, which diminishes the dipole moment of the electronic shift additionally. However, the large displacement of electron density from one part of the $\pi$-system to another enforces a geometrical equilibration of the nuclei which triggers the emission event to take place from a considerably relaxed excited state. As a consequence, the fluorescence is significantly red-shifted, Stokes shifts are large and fluorescence efficiencies decrease when the expansion of the oligoene moiety

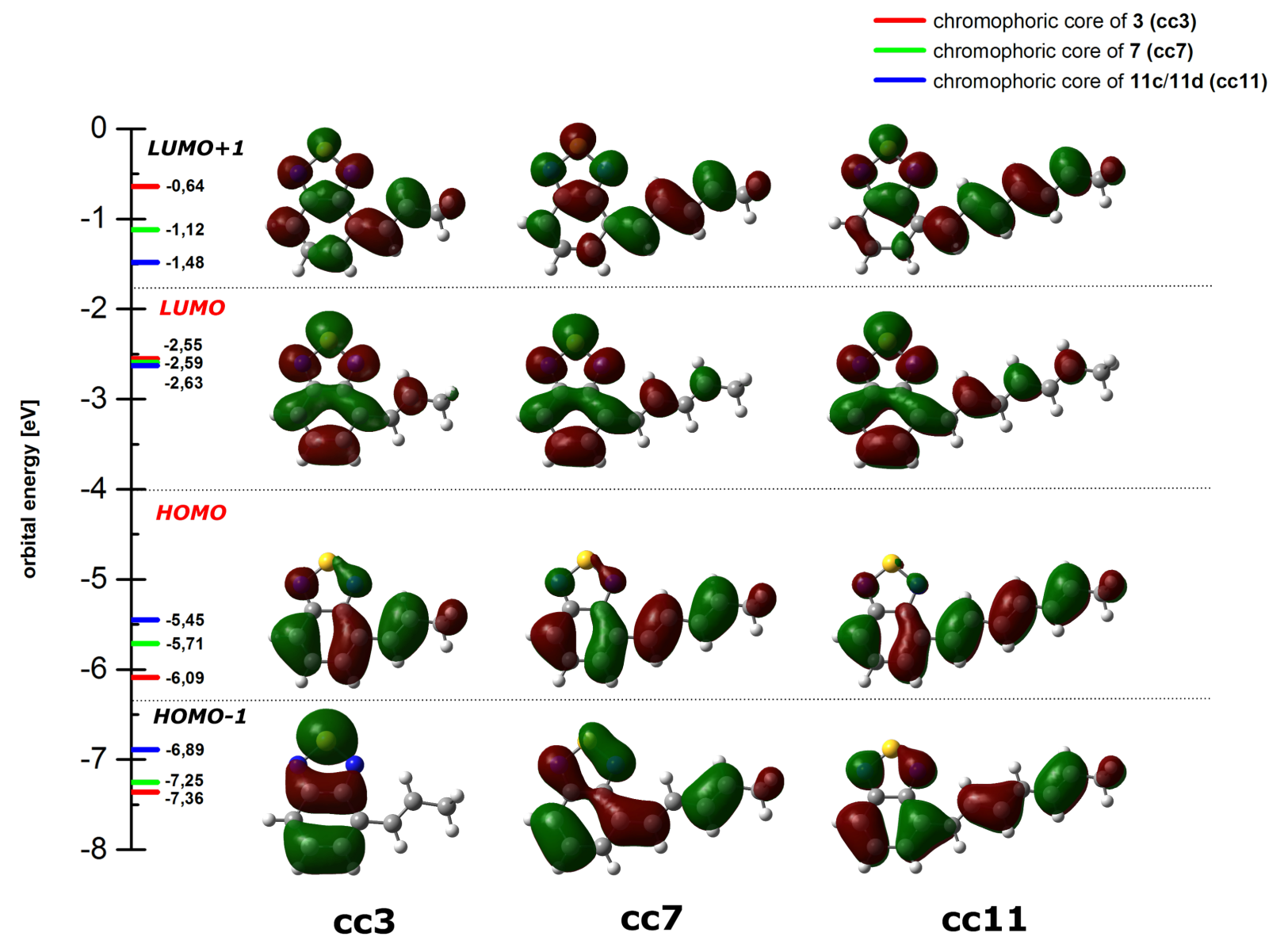

Figure 3: Frontier orbital energies (DFT) and their pictorial representation for the chromophoric cores (cc) of 3, 7, and $\mathbf{1 1 .}$ 
induces a pronounced geometrical relaxation upon excitation. Furthermore, as double bonds are added, the structure starts to resemble polyene systems whose fluorescence quantum yields are known to be quite modest. For comparison, a prototypical pentaene motif exhibits a fluorescence quantum yield of 0.06 in EtOH [23]. Our fatty acids 11c and 11d, however, which can be regarded as terminally substituted pentaene derivatives, can still reach values of 0.18 in THF.

\section{Conclusion}

In conclusion, we have developed a robust approach to three oligoene-shaped fluorescent fatty acids whose fluorescence efficiency is markedly boosted by an unpolar benzo $[c][1,2,5]$ thiadiazole (BTD) moiety as terminal headgroup. Wittig reactions in combination with Horner-Wadsworth-Emmons reactions proved to be the method of choice to access the desired structures, which vary only in the grade of unsaturation while the length of their hydrocarbon chain is maintained. The absorption properties were thus modulated by the number of double bonds ranging from $\lambda^{\mathrm{A}}{ }_{\text {max }}=374 \mathrm{~nm}$ (one double bond) to $\lambda^{\mathrm{A}}$ max $=$ $412 \mathrm{~nm}$ (three double bonds) which matches the requirements for modern laser equipments to trigger efficient excitation. All three variants show remarkably large Stokes shifts ranging from $4900-5700 \mathrm{~cm}^{-1}$ and fluorescence quantum yields in the range of 0.18 to 0.44 . As a set of geometrically similar, but spectroscopically different fluorescent probes we believe that these fatty acids might find interest as useful candidates to study the sensitive hydrophobic area of membranes in terms of domain formation or as labeling agents in general.

\section{Experimental}

General. All solvents for column chromatography were distilled before use unless otherwise stated. Tetrahydrofuran (THF) and diethyl ether $\left(\mathrm{Et}_{2} \mathrm{O}\right)$ were distilled from sodium/ benzophenone under an argon atmosphere. Dichloromethane $\left(\mathrm{CH}_{2} \mathrm{Cl}_{2}\right)$ and tetrachloromethane $\left(\mathrm{CCl}_{4}\right)$ were distilled from $\mathrm{CaCl}_{2}$ under an argon atmosphere. All other solvents were used as analytical grade and were stored over suitable molecular sieves ( $3 \AA$ or $4 \AA$ ). Air and moisture sensitive reactions were carried out in oven-dried or flame-dried glassware, septumcapped under atmospheric pressure of argon. Commercially available compounds were used without further purification unless otherwise stated. Absolute fluorescence quantum yields were determined using a PTI QuantaMaster 40 UV-vis spectrofluorometer equipped with an integrating sphere. The provided corrections for excitation and emission were applied.

(E)-13-(Benzo $[c][1,2,5]$ thiadiazol-4-yl)tridec-12-enoic acid (3): The corresponding Wittig salt $(165 \mathrm{mg}, 0.305 \mathrm{mmol}$, 1.0 equiv) was suspended in THF $(1 \mathrm{~mL})$. Methyllithium $(1.5 \mathrm{M}$ in diethyl ether, $0.44 \mathrm{~mL}, 0.670 \mathrm{mmol}, 2.2$ equiv) was added at $-78^{\circ} \mathrm{C}$ and the reaction mixture was warmed to $\mathrm{rt}$ over $30 \mathrm{~min}$. A solution of aldehyde 1 in THF $(1 \mathrm{~mL})$ was added at $-78^{\circ} \mathrm{C}$ while the solution turns nearly colourless. After 15 min methyllithium (1.5 $\mathrm{M}$ in diethyl ether, $0.22 \mathrm{~mL}, 0.336 \mathrm{mmol}$, 1.1 equiv) was added again at $-78{ }^{\circ} \mathrm{C}$ and the reaction mixture was warmed to $-30{ }^{\circ} \mathrm{C}$ for $90 \mathrm{~min}$. $\mathrm{HCl}$ was added $(1 \mathrm{M}$ in diethyl ether, $0.67 \mathrm{~mL}, 0.670 \mathrm{mmol}, 2.2$ equiv) and the reaction was warmed to $\mathrm{rt}$ for $2 \mathrm{~h}$. The reaction was quenched with excess of $\mathrm{HCOOH}$ and the crude product was adsorbed directly on silica. Column chromatography ( $5 \%$ EtOAc, $0.1 \% \mathrm{HCOOH}$ $\rightarrow 6 \%$ EtOAc, $0.15 \% \mathrm{HCOOH}$ in pentane) gave $11 \mathrm{mg}$ of trans-fatty acid with still $10 \%$ of the corresponding cis-isomer. The crude product was suspended in $80 \mathrm{~mL}$ of degassed $n$-hexane and treated with $6 \mu \mathrm{L}$ of saturated solution of $\mathrm{I}_{2}$ in $n$-hexane. The reaction mixture was heated to $70{ }^{\circ} \mathrm{C}$ for $2.5 \mathrm{~h}$. After removal of solvent fatty acid $\mathbf{3}$, a pale yellow solid, was obtained as trans-isomer without loss of material. It should be mentioned that the compound is first dissolved in tiny amounts of THF before hexane is added to yield a fine suspension. ${ }^{1} \mathrm{H}$ NMR (300 MHz, THF- $\left.d_{8}\right) \delta 1.20-1.65(\mathrm{~m}, 16 \mathrm{H}), 2.20(\mathrm{t}, J=$ 7.3, 2H, $\left.\mathrm{CH}_{2} \mathrm{COOH}\right), 2.34(\mathrm{~m}, 2 \mathrm{H}), 6.92(\mathrm{~m}, 1 \mathrm{H}), 7.17(\mathrm{~m}, 1 \mathrm{H})$, $7.55(\mathrm{~m}, 2 \mathrm{H}), 7.83(\mathrm{dd}, J=7.3,2.6 \mathrm{~Hz}, 1 \mathrm{H}):{ }^{13} \mathrm{C} \mathrm{NMR}$ $\left(75 \mathrm{MHz}, \mathrm{THF}-d_{8}\right) \delta 29.58,29.69,29.75,29.79,29.94,29.99$, $33.72,34.12,119.7,126.0,126.5,129.9,131.5,137.1,153.7$, 156.1, 173.9); IR (ATR) $\tilde{v}\left(\mathrm{~cm}^{-1}\right): 2919,2850,1696,1532$, 1466, 1428, 1302, 1263, 1237, 1209, 967, 907, 756; HRMS (ESI) $\mathrm{m} / z$ : calcd for $\mathrm{C}_{19} \mathrm{H}_{26} \mathrm{~N}_{2} \mathrm{O}_{2} \mathrm{SNa}^{+}, 369.16072$; found, 369.16088 .

(E)-3-(Benzo[c] $[1,2,5]$ thiadiazol-4-yl)prop-2-en-1-ol (6): To a solution of triethyl phosphonoacetate $(266 \mathrm{mg}, 1.18 \mathrm{mmol}$, 1.3 equiv) in THF ( $5 \mathrm{~mL})$ was added $n$-butyllithium $(2.5 \mathrm{M}$, $0.48 \mathrm{~mL}, 1.18 \mathrm{mmol}, 1.3$ equiv) dropwise at $0{ }^{\circ} \mathrm{C}$. After $15 \mathrm{~min}$ aldehyde 1 was added as solid. Stirring was continued for $1 \mathrm{~h}$ at $0{ }^{\circ} \mathrm{C}$. At $-78{ }^{\circ} \mathrm{C} \mathrm{BF}_{3} \cdot \mathrm{OEt}_{2}(0.15 \mathrm{~mL}, 1.18 \mathrm{mmol}, 1.3$ equiv) was added and directly afterwards DIBAL (1 $\mathrm{M}$ in hexane, $3.7 \mathrm{~mL}$, $3.65 \mathrm{mmol}, 4$ equiv) was added. Stirring was continued at $-78^{\circ} \mathrm{C}$ for $1 \mathrm{~h}$. The reaction was quenched with excess of $\mathrm{MeOH}$ at $-78{ }^{\circ} \mathrm{C}$, warmed to $\mathrm{rt}$ and treated with excess of Rochelle salt solution. Stirring continued vigorously at $\mathrm{rt}$ for $1 \mathrm{~h}$. After an aqueous work-up with EtOAc the crude product was submitted to column chromatography on silica gel $(30 \%$ EtOAc in pentane $)$ to give $153 \mathrm{mg}(0.80 \mathrm{mmol}, 87 \%)$ of pure alcohol 6, a pale yellow solid, as trans-isomer. ${ }^{1} \mathrm{H}$ NMR $\left(300 \mathrm{MHz}, \mathrm{CDCl}_{3}\right) \delta 1.95(\mathrm{~s}, 1 \mathrm{H}, \mathrm{OH}), 4.48(\mathrm{dd}, J=5.3,1.4$ $\left.\mathrm{Hz}, 2 \mathrm{H}, \mathrm{CH}_{2} \mathrm{OH}\right), 7.11(\mathrm{~m}, 1 \mathrm{H}), 7.26(\mathrm{~m}, 1 \mathrm{H}), 7.54(\mathrm{~m}, 2 \mathrm{H})$, $7.88(\mathrm{dd}, J=7.8,2.0 \mathrm{~Hz}, 1 \mathrm{H}) ;{ }^{13} \mathrm{C} \mathrm{NMR}\left(75 \mathrm{MHz}, \mathrm{CDCl}_{3}\right) \delta$ $63.8,120.3,126.3,126.8,129.5,130.0,134.4,153.1,155.4$; IR (ATR) $\tilde{v}\left(\mathrm{~cm}^{-1}\right): 3315,3067,2898,2854,1533,1084,1044$, 996, 969, 908, 754; HRMS (EI) $m / z$ : calcd for $\mathrm{C}_{9} \mathrm{H}_{8} \mathrm{~N}_{2} \mathrm{OS}$, 192.03573; found, 192.03451 . 
(10E,12E)-13-(Benzo[c][1,2,5]thiadiazol-4-yl)tridec-10,12dienoic acid (7): To a solution of alcohol 6 (160 mg, $0.832 \mathrm{mmol}, 1.0$ equiv) in DCM ( $8 \mathrm{~mL})$ was added $\mathrm{MnO}_{2}$ ( $1.5 \mathrm{~g}, 16.6 \mathrm{mmol}, 20$ equiv) at rt. Stirring was continued for 45 min. A mixture of $\mathrm{SiO}_{2} / \mathrm{Al}_{2} \mathrm{O}_{3}$ (1:1) was added and the solvent removed to obtain the adsorbed crude product. A short column filtration (20\% EtOAc in pentane) gave $102 \mathrm{mg}$ of the corresponding aldehyde which was used directly in the next step. The corresponding Wittig salt $(363 \mathrm{mg}, 0.707 \mathrm{mmol}$, 1.3 equiv) was suspended in THF $(5 \mathrm{~mL})$. NaHMDS ( $1 \mathrm{M}$ in THF, $1.40 \mathrm{~mL}, 1.40 \mathrm{mmol}, 2.6$ equiv) was added at rt. Stirring was continued until a red solution was established (10 min). At $0{ }^{\circ} \mathrm{C}$ freshly prepared aldehyde dissolved in THF $(2 \mathrm{~mL})$ was added and stirring continued for $1 \mathrm{~h}$ at $0{ }^{\circ} \mathrm{C}$. The reaction was quenched with some excess of $\mathrm{HCOOH}$ and the reaction mixture was directly adsorbed on silica. Column chromatography ( $5 \%$ EtOAc, $0.1 \% \mathrm{HCOOH} \rightarrow 7 \%$ EtOAc, $0.1 \% \mathrm{HCOOH}$ in pentane) gave $100 \mathrm{mg}(0.290 \mathrm{mmol}, 54 \%)$ of fluorescent fatty acid 7 as cis-trans mixture ( $\approx 15 \%$ cis-isomer). Isomerization in $300 \mathrm{~mL}$ of degassed $n$-hexane with $30 \mu \mathrm{L}$ of saturated $\mathrm{I}_{2}$ solution in $n$-hexane at $65{ }^{\circ} \mathrm{C}$ for $90 \mathrm{~min}$ gave compound 7 , a yellow solid, as pure all-trans-isomer after removal of solvents. It should be mentioned that the compound is first dissolved in tiny amounts of THF before hexane is added to yield a fine suspension. ${ }^{1} \mathrm{H}$ NMR (300 MHz, THF- $\left.d_{8}\right) \delta 1.20-1.65(\mathrm{~m}, 12 \mathrm{H})$, 2.13-2.25 (m, 4H, $\left.\mathrm{CH}_{2} \mathrm{COOH},-\mathrm{C}=\mathrm{CCH}_{2}\right), 5.99$ (dd, $J=14.7$, $7.1 \mathrm{~Hz}, 1 \mathrm{H}), 6.34(\mathrm{~m}, 1 \mathrm{H}), 6.96(\mathrm{~d}, J=15.7 \mathrm{~Hz}, 1 \mathrm{H}), 7.50-7.63$ (m, 2H), $7.72(\mathrm{dd}, J=15.7,10.6 \mathrm{~Hz}, 1 \mathrm{H}), 7.78-7.88(\mathrm{~m}, 1 \mathrm{H})$; ${ }^{13} \mathrm{C}$ NMR $\left(75 \mathrm{MHz}, \mathrm{THF}-d_{8}\right) \delta 30.11,30.13,30.23,30.28$, $30.33,33.84,34.25,120.3,126.9,126.9,130.5,132.1,132.4$, 135.8, 138.3, 154.1, 156.7, 174.5; IR (ATR) $\tilde{v}\left(\mathrm{~cm}^{-1}\right): 3031$, 2994, 2919, 2851, 1703, 1469, 1415, 1310, 1287, 1257, 1219, $988,897,829,747$; HRMS (ESI) $m / z$ : calcd for $\mathrm{C}_{19} \mathrm{H}_{24} \mathrm{~N}_{2} \mathrm{O}_{2} \mathrm{SNa}^{+}$, 367.14507; found, 369.14518 .

Methyl (2E,4E)-5-(benzo[c][1,2,5]thiadiazol-4-yl)penta-2,4dienoate (9): To a solution of conjugated phosphonate 8 (189 mg, $0.792 \mathrm{mmol}, 1.3$ equiv) in THF $(5 \mathrm{~mL})$ was added $n$-butyllithium (2.5 M, $0.32 \mathrm{~mL}, 0.792 \mathrm{mmol}, 1.3$ equiv) at $0{ }^{\circ} \mathrm{C}$. Stirring was continued at this temperature for $15 \mathrm{~min}$. A solution of aldehyde $\mathbf{1}$ (100 mg, $0.609 \mathrm{mmol}, 1$ equiv) in THF $\left(2 \mathrm{~mL}\right.$ ) was added dropwise at $0{ }^{\circ} \mathrm{C}$ and strirring continued for $1 \mathrm{~h}$. The reaction was then quenched with aqueous saturated $\mathrm{NH}_{4} \mathrm{Cl}$ solution and worked-up with DCM. Column chromatography on silica gel (5\% EtOAc, 20\% DCM in pentane) gave $124 \mathrm{mg}(0.503 \mathrm{mmol}, 83 \%)$ of highly fluorescent ester 9 as a yellow solid. ${ }^{1} \mathrm{H} \mathrm{NMR}\left(300 \mathrm{MHz}, \mathrm{CDCl}_{3}\right) \delta 3.80$ (s, 3H, OMe), $6.16(\mathrm{~m}, 1 \mathrm{H}), 7.31(\mathrm{~m}, 1 \mathrm{H}), 7.45-7.65(\mathrm{~m}, 3 \mathrm{H}), 7.80-8.00(\mathrm{~m}$, $2 \mathrm{H}) ;{ }^{13} \mathrm{C} \mathrm{NMR}\left(75 \mathrm{MHz}, \mathrm{CDCl}_{3}\right) \delta 51.65,121.7,122.4,128.9$, $129.4,129.5,131.7,136.0,145.0,152.9,155.5,167.4$; IR (ATR) $\tilde{v}\left(\mathrm{~cm}^{-1}\right): 2993,2956,1711,1619,1528,1462,1330$,
1244, 1225, 1137, 990, 837, 750; HRMS (ESI) $\mathrm{m} / \mathrm{z}$ : calcd for $\mathrm{C}_{12} \mathrm{H}_{10} \mathrm{~N}_{2} \mathrm{O}_{2} \mathrm{SNa}^{+}$, 269.03552; found, 269.03557.

\section{(2E,4E)-5-(Benzo[c][1,2,5]thiadiazol-4-yl)penta-2,4-dien-1-ol} (10): To a solution of ester 9 (124 mg, $0.503 \mathrm{mmol}, 1.0$ equiv) in DCM ( $3 \mathrm{~mL})$ was added DIBAL ( $1 \mathrm{M}$ in hexane, $1.51 \mathrm{~mL}$, $1.51 \mathrm{mmol}, 3$ equiv) at $-20{ }^{\circ} \mathrm{C}$. Stirring continued for $1 \mathrm{~h}$ at $-20{ }^{\circ} \mathrm{C}$ and for $1 \mathrm{~h}$ at $0{ }^{\circ} \mathrm{C}$. $\mathrm{MeOH}$ was added, then Rochelle salt solution and vigorous stirring continued for $1 \mathrm{~h}$ at $\mathrm{rt}$. After an aqueous work-up the crude product was submitted to column chromatography on silica gel (20\% EtOAc, 30\% DCM $\rightarrow 30 \%$ EtOAc, 30\% DCM in pentane) to give $85 \mathrm{mg}(0.390 \mathrm{mmol}$, $77 \%)$ of the pure alcohol 10 as a yellow solid. ${ }^{1} \mathrm{H}$ NMR $\left(300 \mathrm{MHz}, \mathrm{CDCl}_{3}\right) \delta 1.75(\mathrm{~s}, 1 \mathrm{H}, \mathrm{OH}), 4.31(\mathrm{~d}, J=5.5 \mathrm{~Hz}, 2 \mathrm{H}$, $\left.\mathrm{CH}_{2} \mathrm{OH}\right), 6.14(\mathrm{~m}, 1 \mathrm{H}), 6.54(\mathrm{~m}, 1 \mathrm{H}), 7.03(\mathrm{~d}, J=15.7 \mathrm{~Hz}, 1 \mathrm{H})$, $7.48-7.58(\mathrm{~m}, 2 \mathrm{H}) 7.67$ (dd, $J=15.7,10.4 \mathrm{~Hz}, 1 \mathrm{H}), 7.85(\mathrm{dd}, J$ $=7.8,2.0 \mathrm{~Hz}, 1 \mathrm{H}) ;{ }^{13} \mathrm{C} \mathrm{NMR}\left(75 \mathrm{MHz}, \mathrm{CDCl}_{3}\right) \delta 63.34,120.1$, 126.6, 128.4, 129.6, 130.6, 131.7, 133.5, 134.6, 153.1, 155.5); IR (ATR) $\tilde{v}\left(\mathrm{~cm}^{-1}\right): 3416,3358,3014,2991,1529,1483,1275$, 1155, 1094, 1066, 980, 905, 837, 742; HRMS (ESI) $\mathrm{m} / \mathrm{z}$ : calcd for $\mathrm{C}_{11} \mathrm{H}_{10} \mathrm{~N}_{2} \mathrm{OSNa}^{+}$, 241.04060; found, 241.04071.

\section{$(8 E, 10 E, 12 E)-8-(B e n z o[c][1,2,5]$ thiadiazol-4-yl)tridec-} 8,10,12-trienoic acid (11c): To a solution of $10(40 \mathrm{mg}$, $0.183 \mathrm{mmol}, 1.0$ equiv) in DCM (1.5 mL) was added $\mathrm{MnO}_{2}$ (318 mg, $3.66 \mathrm{mmol}, 20$ equiv) at rt. Stirring was continued for 45 min. A mixture of $\mathrm{SiO}_{2} / \mathrm{Al}_{2} \mathrm{O}_{3}(1: 1)$ was added and the solvent removed to obtain the adsorbed crude product. A short column filtration (20\% EtOAc in pentane) gave $34 \mathrm{mg}$ of the corresponding aldehyde (86\%) which was used directly in the next step. The corresponding Wittig salt (116 mg, $0.238 \mathrm{mmol}$, 1.3 equiv) was suspended in THF ( $2 \mathrm{~mL})$. NaHMDS ( $1 \mathrm{M}$ in THF, $0.78 \mathrm{~mL}, 0.480 \mathrm{mmol}, 2.6$ equiv) was added at rt. Stirring was continued until a red solution was established (10 min). At $0{ }^{\circ} \mathrm{C}$ freshly prepared aldehyde dissolved in THF $(1 \mathrm{~mL})$ was added and stirring continued for $1 \mathrm{~h}$ at $0{ }^{\circ} \mathrm{C}$. The reaction was quenched with $\mathrm{HCOOH}$ ( 3 equiv) and directly adsorbed on silica/ $\mathrm{Al}_{2} \mathrm{O}_{3}$ (1:1). Column chromatography $(10 \%$ EtOAc in pentane to remove rests of aldehyde, then 5\% EtOAc, $0.1 \%$ $\mathrm{HCOOH} \rightarrow 6 \%$ EtOAc, $0.15 \% \mathrm{HCOOH}$ in pentane) gave $20 \mathrm{mg}(0.058 \mathrm{mmol}, 37 \%)$ of fatty acid. In some cases size exclusion chromatography in $\mathrm{CHCl}_{3}$ was helpful to remove rests of Wittig salt. Isomerization was performed in $n$-hexane (200 mL, degassed) with $15 \mu \mathrm{L}$ of saturated $\mathrm{I}_{2}$-solution in $n$-hexane for $90 \mathrm{~min}$ at $65{ }^{\circ} \mathrm{C}$. It should be mentioned that the compound was first dissolved in tiny amounts of THF before hexane was added to yield a fine suspension. After removal of solvents fatty acid 11c, a yellow solid, was obtained as pure alltrans isomer. ${ }^{1} \mathrm{H}$ NMR $\left(300 \mathrm{MHz}, \mathrm{THF}-d_{8}\right) \delta 1.20-1.65(\mathrm{~m}$, $8 \mathrm{H}), 2.06-2.26\left(\mathrm{~m}, 4 \mathrm{H}, \mathrm{CH}_{2} \mathrm{COOH},-\mathrm{C}=\mathrm{CCH}_{2}\right), 5.83(\mathrm{dd}$, $J=15.1,7.1 \mathrm{~Hz}, 1 \mathrm{H}), 6.21(\mathrm{~m}, 1 \mathrm{H}), 6.45(\mathrm{~m}, 2 \mathrm{H}), 7.03(\mathrm{~d}$, 
$J=15.6 \mathrm{~Hz}, 1 \mathrm{H}), 7.50-7.66(\mathrm{~m}, 2 \mathrm{H}), 7.72-7.86(\mathrm{~m}, 2 \mathrm{H})$; ${ }^{13} \mathrm{C}$ NMR $\left(75 \mathrm{MHz}, \mathrm{THF}-d_{8}\right) \delta 25.78,29.88,29.94,30.11$, $33.75,34.21,120.4,127.1,128.2,130.5,131.8,132.0,132.4$, 135.7, 136.5, 137.2, 154.1, 156.7, 174.4; IR (ATR) $\tilde{v}\left(\mathrm{~cm}^{-1}\right)$ : 3009, 2927, 2853, 1695, 1526, 1265, 993, 906, 750; HRMS (ESI) $\mathrm{m} / z$ : calcd for $\mathrm{C}_{19} \mathrm{H}_{24} \mathrm{~N}_{2} \mathrm{O}_{2} \mathrm{SNa}^{+}$, 365.12942; found, 365.12956 .

(16E,18E,20E)-21-(Benzo $[c][1,2,5]$ thiadiazol-4-yl)henicos16,18,20-trienoic acid (11d): To a solution of alcohol 10 (40 mg, $0.183 \mathrm{mmol}, 1.0$ equiv) in DCM $(1.5 \mathrm{~mL})$ was added $\mathrm{MnO}_{2}$ (318 mg, $3.66 \mathrm{mmol}, 20$ equiv) at rt. Stirring was continued for $45 \mathrm{~min}$. A mixture of $\mathrm{SiO}_{2} / \mathrm{Al}_{2} \mathrm{O}_{3}(1: 1)$ was added and the solvent was removed to obtain the adsorbed crude product. A short column filtration (20\% EtOAc in pentane) gave $31 \mathrm{mg}$ of the corresponding aldehyde $(78 \%)$ which was used directly in the next step. The corresponding Wittig salt $(111 \mathrm{mg}$, $0.186 \mathrm{mmol}, 1.3$ equiv) was suspended in THF $(1.5 \mathrm{~mL})$. NaHMDS ( $1 \mathrm{M}$ in THF, $0.37 \mathrm{~mL}, 0.372 \mathrm{mmol}, 2.6$ equiv) was added at rt. Stirring was continued until a red solution was established $(10 \mathrm{~min})$. At $0{ }^{\circ} \mathrm{C}$ freshly prepared aldehyde dissolved in THF $(1 \mathrm{~mL})$ was added and stirring continued for $1 \mathrm{~h}$ at $0{ }^{\circ} \mathrm{C}$. The reaction was quenched with $\mathrm{HCOOH}$ ( 3 equiv) and directly adsorbed on silica/ $\mathrm{Al}_{2} \mathrm{O}_{3}(1: 1)$. Column chromatography $(10 \%$ EtOAc in pentane to remove rests of aldehyde, then $5 \%$ EtOAc, $0.1 \% \mathrm{HCOOH} \rightarrow 7 \%$ EtOAc, $0.1 \% \mathrm{HCOOH}$ in pentane) gave $45 \mathrm{mg}$ ( $0.099 \mathrm{mmol}, 54 \%)$ of fatty acid. Isomerization was performed in $n$-hexane $(300 \mathrm{~mL}$, degassed) with $20 \mu \mathrm{L}$ of saturated $\mathrm{I}_{2}$-solution in $n$-hexane for $90 \mathrm{~min}$ at $65^{\circ} \mathrm{C}$. It should be mentioned that the compound was first dissolved in tiny amounts of THF before hexane was added to yield a fine suspension. After removal of solvents fatty acid 11d, a yellow solid, is usually obtained as pure all-trans-isomer. ${ }^{1} \mathrm{H}$ NMR $\left(300 \mathrm{MHz}, \mathrm{THF}-d_{8}\right) \delta 1.20-1.65(\mathrm{~m}, 8 \mathrm{H}), 2.06-2.26(\mathrm{~m}, 4 \mathrm{H}$, $\left.\mathrm{CH}_{2} \mathrm{COOH},-\mathrm{C}=\mathrm{CCH}_{2}\right), 5.82(\mathrm{dd}, J=15.1,7.1 \mathrm{~Hz}, 1 \mathrm{H}), 6.20$ (m, 1H), $6.45(\mathrm{~m}, 2 \mathrm{H}), 7.03(\mathrm{~d}, J=15.6 \mathrm{~Hz}, 1 \mathrm{H}), 7.50-7.66(\mathrm{~m}$, $2 \mathrm{H}), 7.72-7.86(\mathrm{~m}, 2 \mathrm{H}) ;{ }^{13} \mathrm{C}$ NMR $\left(75 \mathrm{MHz}, \mathrm{THF}-d_{8}\right) \delta 29.59$, 29.65, 29.74, 29.80, 29.93, 29.95, 30.05, 30.08, 33.28, 33.72, $119.8,126.6,127.7,123.0,131.3,131.5,131.9,135.2,135.9$, 136.8, 153.6, 156.2, 173.9; IR (ATR) $\tilde{v}\left(\mathrm{~cm}^{-1}\right): 3010,2920$, 2849, 1696, 1527, 1464, 1260, 993, 927, 802, 750, 725; HRMS (ESI) $m / z$ : calcd for $\mathrm{C}_{27} \mathrm{H}_{38} \mathrm{~N}_{2} \mathrm{O}_{2} \mathrm{SNa}^{+}$, 477.25462; found, 477.25542 .

\section{Supporting Information}

\section{Supporting Information File 1}

Copies of ${ }^{1} \mathrm{H}$ and ${ }^{13} \mathrm{C}$ NMR spectra.

[http://www.beilstein-journals.org/bjoc/content/

supplementary/1860-5397-12-270-S1.pdf]

\section{Acknowledgements}

We are grateful to the Deutsche Forschungsgemeinschaft (DFG, SFB 803 "Functionality controlled by organization in and between membranes", project A05) and the Fonds der Chemischen Industrie (FCI) for financial support (Dozentenstipendium to D.B.W.). We thank Martin Bröring (TU Braunschweig) for the possibility of measuring quantum yields by the instrument in his labs.

\section{References}

1. Simons, K.; Ikonen, E. Nature 1997, 387, 569-572. doi:10.1038/42408

2. Sonnino, S.; Prinetti, A.; Mauri, L.; Chigorno, V.; Tettamanti, G. Chem. Rev. 2006, 106, 2111-2125. doi:10.1021/cr0100446

3. Brown, D. A.; London, E. J. Biol. Chem. 2000, 275, 17221-17224. doi:10.1074/jbc.R000005200

4. Silvius, J. R. Biochim. Biophys. Acta, Biomembr. 2003, 1610, 174-183. doi:10.1016/S0005-2736(03)00016-6

5. Windschiegl, B.; Orth, A.; Römer, W.; Berland, L.; Stechmann, B.; Bassereau, P.; Johannes, L.; Steinem, C. PLoS One 2009, 4, e6238. doi:10.1371/journal.pone.0006238

6. Ross, M.; Steinem, C.; Galla, H.-J.; Janshoff, A. Langmuir 2001, 17, 2437-2445. doi:10.1021/la001617x

7. Schütte, O. M.; Ries, A.; Orth, A.; Patalag, L. J.; Römer, W.; Steinem, C.; Werz, D. B. Chem. Sci. 2014, 5, 3104-3114. doi:10.1039/c4sc01290a

8. Schütte, O. M.; Patalag, L. J.; Weber, L. M. C.; Ries, A.; Römer, W.; Werz, D. B.; Steinem, C. Biophys. J. 2015, 108, 2775-2778. doi:10.1016/j.bpj.2015.05.009

9. Lipsky, N. G.; Pagano, R. E. Proc. Natl. Acad. Sci. U. S. A. 1983, 80, 2608-2612. doi:10.1073/pnas.80.9.2608

10. Lipsky, N. G.; Pagano, R. E. Science 1985, 228, 745-747. doi:10.1126/science. 2581316

11. Pagano, R. E.; Martin, O. C.; Kang, H. C.; Haugland, R. P. J. Cell Biol. 1991, 113, 1267-1279. doi:10.1083/jcb.113.6.1267

12. Kaiser, R. D.; London, E. Biochim. Biophys. Acta 1998, 1375, 13-22. doi:10.1016/S0005-2736(98)00127-8

13. Patalag, L. J.; Jones, P. G.; Werz, D. B. Angew. Chem. 2016, 128, 13534-13539. doi:10.1002/ange.201606883 Angew. Chem., Int. Ed. 2016, 55, 13340-13344. doi:10.1002/anie.201606883

14. Somerharju, P. Chem. Phys. Lipids 2002, 116, 57-74. doi:10.1016/S0009-3084(02)00020-8

15. Patalag, L. J.; Werz, D. B. J. Org. Chem. 2012, 77, 5297-5304. doi:10.1021/jo300624h

16. Kuerschner, L.; Ejsing, C. S.; Ekroos, K.; Shevchenko, A.; Anderson, K. I.; Thiele, C. Nat. Methods 2005, 2, 39-45. doi:10.1038/nmeth728

17. Negishi, E.; Alimardanov, A.; Xu, C. Org. Lett. 2000, 2, 65-67. doi:10.1021/ol990336h

18. Zeng, F.; Negishi, E. Org. Lett. 2001, 3, 719-722. doi:10.1021/ol000384y

19. Zeng, F.; Negishi, E. Org. Lett. 2002, 4, 703-706. doi:10.1021/ol0102794

20. Ley, S. V.; Smith, S. C.; Woodward, P. R. Tetrahedron Lett. 1988, 29 , 5829-5832. doi:10.1016/S0040-4039(00)82204-2

21. Wittig, G.; Schöllkopf, U. Chem. Ber. 1954, 87, 1318-1330. doi:10.1002/cber.19540870919 
22. Wadsworth, W. S.; Emmons, W. D. J. Am. Chem. Soc. 1961, 83, 1733-1738. doi:10.1021/ja01468a042

23. Nieves, I.; Artetxe, I.; Abad, J. L.; Alonso, A.; Busto, J. V.; Fajarí, L.; Montes, L. R.; Sot, J.; Delgado, A.; Goñi, F. M. Langmuir 2015, 31, 2484-2492. doi:10.1021/la505017x

\section{License and Terms}

This is an Open Access article under the terms of the Creative Commons Attribution License

(http://creativecommons.org/licenses/by/4.0), which permits unrestricted use, distribution, and reproduction in any medium, provided the original work is properly cited.

The license is subject to the Beilstein Journal of Organic Chemistry terms and conditions:

(http://www.beilstein-journals.org/bjoc)

The definitive version of this article is the electronic one which can be found at: doi:10.3762/bjoc. 12.270 